\title{
Development patterns of fringing and barrier reefs in New Caledonia (southwest Pacific)
}

\author{
Guy CABIOCH ${ }^{\mathrm{a}, \mathrm{b} *}$, Thierry CORREGE ${ }^{\mathrm{a}}$, Laurent ' TURPIN ${ }^{\mathrm{c}}$, Christine CASTELLARO ${ }^{\mathrm{d}}$, Jacques RECY ${ }^{\mathrm{a}, \mathrm{b}}$ \\ ${ }^{2}$ IRD, BP A5, 98848 Nouméa ccdcx, New Caledonia \\ ${ }^{b}$ UMR Géosciences Azur 6526 \\ 'Laboratoire des sciences du climat et de l'environnement, CNRS/CEA, avenue de la Terrasse, \\ 91198 Gif-sur-Yvette cedex, France \\ ${ }^{d}$ UPRESA CNRS 6019, Centre de sédimentologie et paléontologie, université de Provence, \\ 13331 Marseille cedex 3, France
}

Revised 10 June 1999; accepted 18 June 1999

\begin{abstract}
In New Caledonia, core data indicate that the fringing reefs grew during the last interglacial and the Holocene, while the barrier reefs developed during several high sea level stands of the Quaternary. These growth periods are archived in a 128-m-long core from Ilot Amédée, offshore of Nouméa. Directly upon the peridotitic substrate (reached at $126.50 \mathrm{~m}$ ), a basal unit comprising abundant rhodoliths, molluses and rare corals is characteristic of the pioneer stage of barrier reef development. Above il, a severely calcitized unit contains corals, molluscs and abundant micritic levels. Then, a sequence punctuated by several minor discontinuities and by a downward increase in diagenetic alteration is found. At $47 \mathrm{~m}$ core depth, a unit, which is thought to be related to isotopic stages 7 and 9 , contains thin beds of coralgal frameworks and muddy detritus. The $125 \mathrm{ka}$-old reef, from 14 to $37 \mathrm{~m}$ core deep, is predominantly composed of biocalcarenites and rare coral colonies. Finally, the Holocene reef is composed of sands and scarce coral buildups. Drilling results indicate that the distributional patterns of the 125-ka-old reef bodies around New Caledonia express an increasing tendency of island subsidence northward, southwestward and more markedly seaward, mainly controlled by isostatic readjustments and margin collapse. (C) 1999 Ifremer / CNRS / IRD / Éditions scientifiques et médicales Elsevier SAS
\end{abstract}

\section{reef growth / neotectonics / New Caledonia / Quaternary}

Résumé -- Mode d'édification des récifs frangeants et barrières de Nouvelle-Calédonie (Sud-Ouest Pacifique). En Nouvelle-Calédonie, l'étude de 39 forages carottés prélevés sur les récifs frangeants, et l'analyse de forages plus profonds réalisés sur le réci barrière, ou à proximilé, apportent de nombreuses donnees sur la constitution et l'édification des récifs modernes et du Quaternaire terminal ainsi que sur le comportement tectonique récent de lîle principale ou « Grande Terre ». Les données fournies par ces forages indiquent que les récifs frangeants se sont édifiés en deux phases, il y a 125000 dns (stade isotopique $5^{\mathrm{e}}$ ) et au cours de la période moderne, alors que le récif barrière s'est édifié au cours de plusieurs hauts niveaux marins successifs du Quaternaire terminal, comme l'indique un forage de $128 \mathrm{~m}$ sur lc récif de l'îlot Amédée situé juste en arrière du récif barrière, à $30 \mathrm{~km}$ au large de Nouméa, le long de la côte sud-ouest. La séquence suivante y est observée : de 116 à $126,50 \mathrm{~m}$, sur le substrat de péridotites, un assemblage pionnier d'organismes caractérisé par d'abondants rhodolithes (corallinacées) et mollusques; de 69,50 à $116 \mathrm{~m}$, de nombreux niveaux riches en algues, foraminifères benthiques et mollusques et quelques niveaux bioconstruits à scléractiniaires et algues encroûtantes ; de 47 à $69,50 \mathrm{~m}$, plusieurs unités composées de niveaux bioclastiques riches en foraminifères benthiques, algues et mollusques caractérisant des environnements sub-récifaux ; de 37 à $47 \mathrm{~m}$, des unités constituées de niveaux riches en débris algaires, de mollusques et de foraminifères benthiques alternant avec des bioconstructions coralliennes. Ces unités sont attribuées aux stades isotopiques 7 ( $210 \mathrm{ka}$ ) et 9 (330 ka) sur la base de la succession stratigraphique ; de 14 à $37 \mathrm{~m}$, une unité récifale, datée de $125 \mathrm{ka}$ par U/Th, principalement composée de biocalcarénites et de constructions coralliennes et algaires. Enfin au sommet,

* Correspondence and reprints: cabioch@ noumea.ird.nc 
le récif holocène composé de sables bioclastiques et de constructions coraliiennes éparses. Dans cette séquence récifale de $126,50 \mathrm{~m}$, on observe, de la base vers le sommet, un appauvrissement des niveaux riches en foraminifères benthiques, mollusques et algues et corrélativement un enrichissement en niveaux bioconstruits à coraux et algues rouges encroûtantes ; ceci traduit une nette évolution de milieux sub-récifaux vers des milieux récifaux sensu stricto. Du point de vue tectonique, la morphologie des récifs modernes et la disposition générale du récif $125 \mathrm{ka}$ autour de la Nouvelle-Calédonie traduisent la tendance à l'augmentation de la subsidence des marges vers le nord et le sud-ouest à partir d'une zone centrale relativement stable. (1) 1999 Ifremer / CNRS / IRD / Éditions scientitiques et médicales Elsevier SAS

\section{croissance récifale / néotectonique / Nouvelle-Calédonie / Quaternaire}

\section{INTRODUCTION}

Located in the southwest Pacific (figure l), the Territory of New Caledonia extends along two NW-SE parallel ridges $\left(\mathrm{N} 150^{\circ} \mathrm{E}\right)$ : the New Caledonia ridge (the northern portion of the Norfolk ridge which is a major lineament of the Australian plate), and the Loyalty ridge (figure I). Nearby, the Australian plate is subducting underneath the Pacific plate to form the New Hebrides Island Arc. This subduction induces a bulge of the Australian plate, that culminates in the Loyalty islands $[20,21]$. The New Caledonia ridge, on top of which lies the main island of New Caledonia, or Grande Terre (between $19^{\circ}$ and $23^{\circ} \mathrm{S}$ ), extends some $400 \mathrm{~km}$, bounded by the New Caledonia basin to the southwest and the Loyalty basin to the northeast (figure 1). The ridge forms a narrow strip of continental margin separated from the Australian mainland in Late Cretaceous times [29].

The structure of the Grande Terre comprises three subparallel units overlapped in the I ate Focene by a peridotitic sheet thrust from north to south $[13,14,37]$. These are: 1) a central Permo-Triassic chain, 2) to the northeast, Permo-Paleogene sediments, metamorphosed during the Eocene obduction, and 3) along the west coast, a basaltic complex ranging in age from Cretaceous to Eocene. Since the obduction, the erosion of the peridotitic sheet has been continuous and the resulting sediments have filled the two adjacent basins $[17,39]$ and induced some isostatic readjustments [21].

The Grande Terre is surrounded by one of the largest reef systems in the world [12]. A barrier reef, which locally splits into two or even three distinct reefs, encloses the island along some $1000 \mathrm{~km}$ of coastline (figure 2). The reefs stretch northward, bounding the extensive Northern Lagoon, and southward, enclosing the Noumea Lagoon. Inner reefs are scattered throughout the lagoonal areas, locally as linear tracts parallel to the shorelines [41]. Fringing reefs are common features in nearshore areas where shallow-water hard substrates are present, especially along the eastern coast.
Here, we present an overview of the mode of edification of the New Caledonian fringing and barrier reefs, based on the analysis of 39 cores recovered from fringing reefs and of four cores from Amédée Ilot, which is situated just behind the barrier reef.

\section{MATERIAL AND METHODS}

Cores were recovered using various coring systems. The core diameter ranges from 4.6 to $3.5 \mathrm{~cm}$, and the depth of the boreholes varies from 4 to $128 \mathrm{~m}$. Recovery, depending on consolidation and porosity, ranged from 10 to $80 \%$. Sections with poor recovery are related to intervals of unconsolidated material and to cavities or caverns (figure 3). The core depths are given in meters with the reef surface as the reference point. Analyses, including faunal and floral identifications were performed using standard optical microscopy, SEM (Scanning Electron Microscopy) X-ray diffraction and specific staining techniques. Coral samples, containing more than $98 \%$ aragonite and showing minimal evidence of aragonitic cement or dissolution, were dated using both conventional and AMS (Accelerator Mass Spectrometry) ${ }^{14} \mathrm{C}$, and TIMS (thermal ionisation mass spectrometry) U/Th methods [42]. ${ }^{14} \mathrm{C}$ dates were converted to calendar years $\mathrm{BP}$ according to the calibration by Stuiver and Reimer [40].

\section{THE INTERNAL STRUCTURE OF THE FRINGING AND BARRIER REEFS}

\subsection{The modern reef}

The Holocene reef unit, which has been growing for the past $8.5 \mathrm{ka}$, settled upon an old reef flat, slightly or severely karstified, in the southeastern and southwestern areas, and directly upon metamorphic or peridotitic substrates in the western, castern and northern arcas (figure 3) [7-9]. 


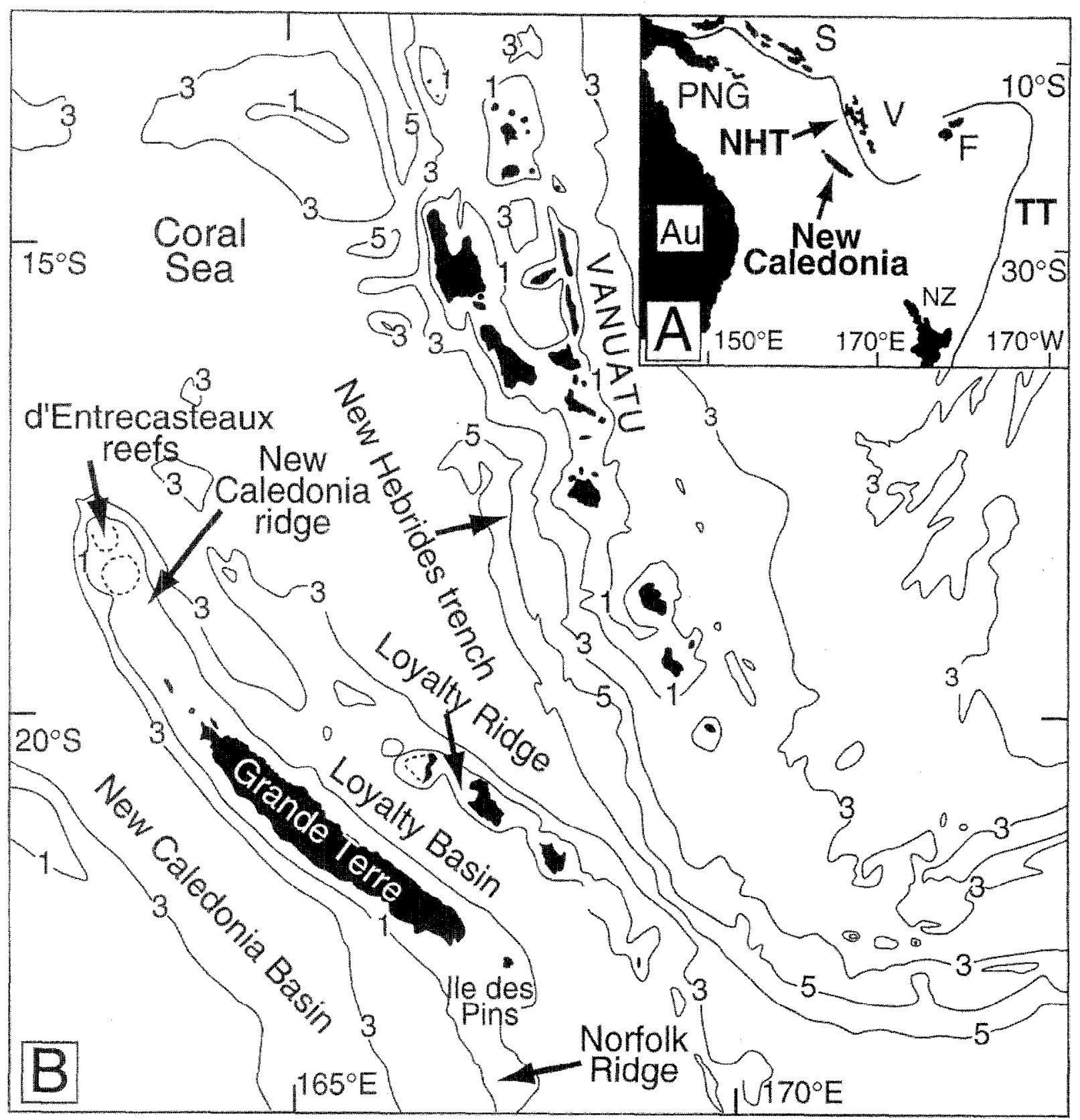

Figure 1. Geodynamical setting of the southwest Pacific (A) and bathymetry in km of the Pacific Ocean in the vicinity of New Caledonia (B). Au: Australia; PNG: Papua New Guinea; S: Solomon Islands; F: Fiji; NZ: New Zealand; TT: Tonga-Kermadec trench; NHT: New Hebrides trench.

The fringing reefs generally consist of two units. The lower unit mainly exhibits fine- to coarse-grained skeletal detritus and branching coral assemblages, including various acroporids, generally typical of low to medium water energy conditions $[19,25]$. The upper unit is typified by corals mainly consisting of in situ massive Porites or faviid colonies with subordinate acroporids, typical of medium to high water energy conditions. A coral rubble facies, consisting of pieces of massive or branching corals bound by coralline algal crusts, is widely distributed in the reef unit (figure 3). Here, the upward replacement of coral facies from branching to massive forms clearly reflects a catch-up style of reef growth in the sense of Neumann and Macintyre [35]. 


\section{BELEP}

\section{ISLANDS}

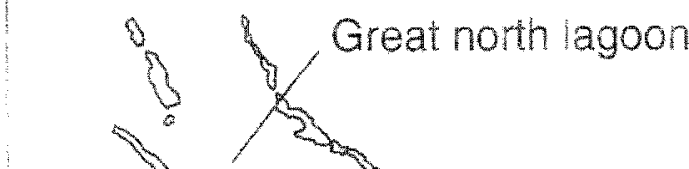

Fringing reet driling area

Barrier reef drilling area

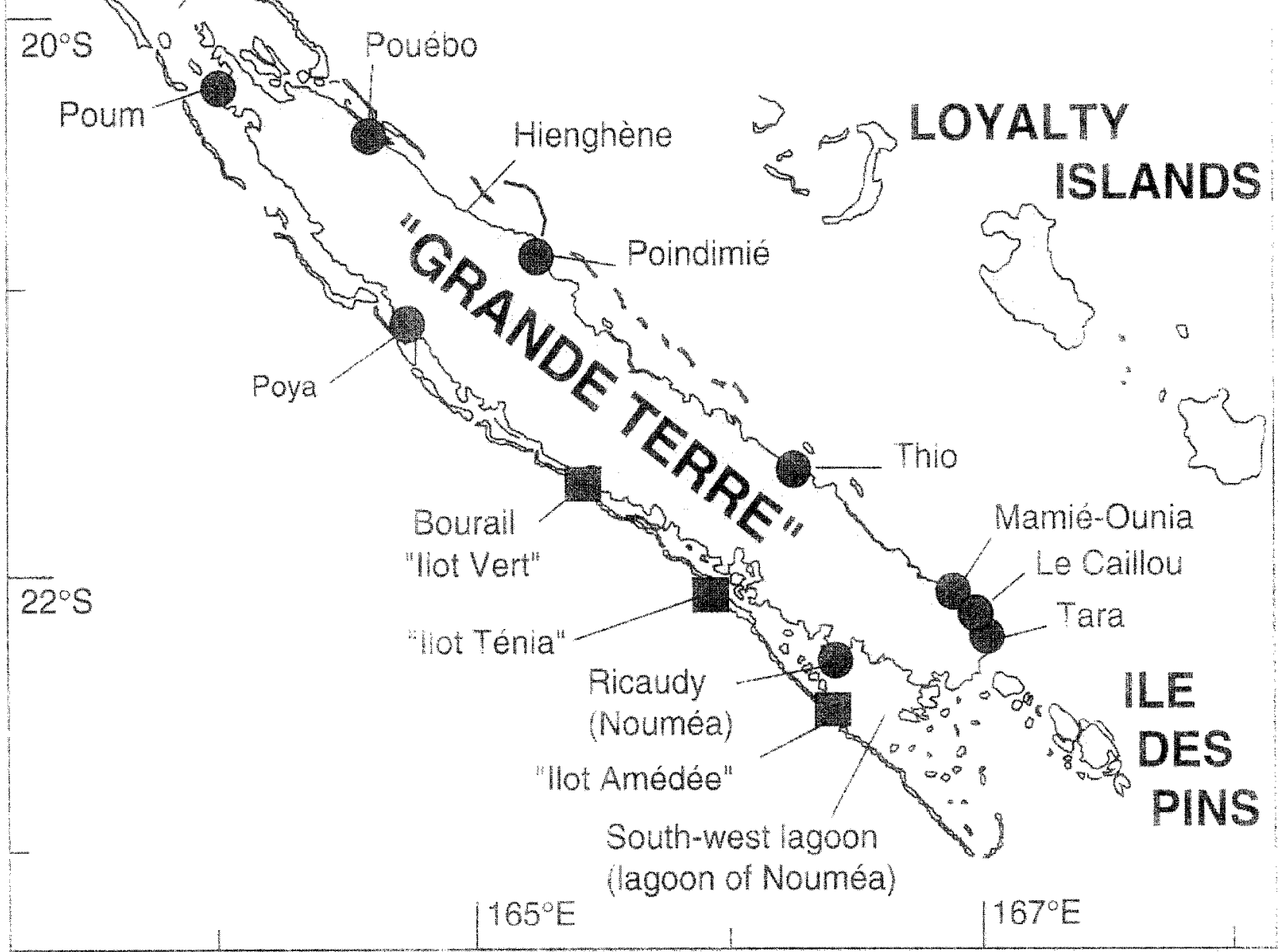

Figure 2. Location of the investigated fringing and barrier reef sites.

Within the barrier reef zone, the internal structure patterns are poorly documented, except in a few areas: at $1 l o t$ Ténia, the Holocene reefal unit displays bioclastic backreef deposits [19]; at $\mathrm{llot}$ Vert, near Bourail, the Holocene reef flat is juxtaposed to the emergent 125 -ka-old reef [ 7 , 18]. On Amédée, all four cores (figure 4) penetrated a Holocene unit which is composed of frameworks consisting mainly of coral colonies in growth position (generally acroporids) and encrusted by coralline algal (Hydroli- thon onkodes) and vermetid veneers. Detrital beds are encountered occasionally (figure 4). By analogies with their modern counterparts, these assemblages are regarded as characterizing reef edges and upper reef slopes exposed to strong wave action, in waters less than $6 \mathrm{~m}$ deep $[11,34]$. It is noteworthy that at $3 \mathrm{~m}$ above the Holocene / 125 ka Pleistocene unconformity, a coral, in growth position, has been dated by U/Th TIMS to 8.235 $\pm 190 \mathrm{yr}[42]$. 


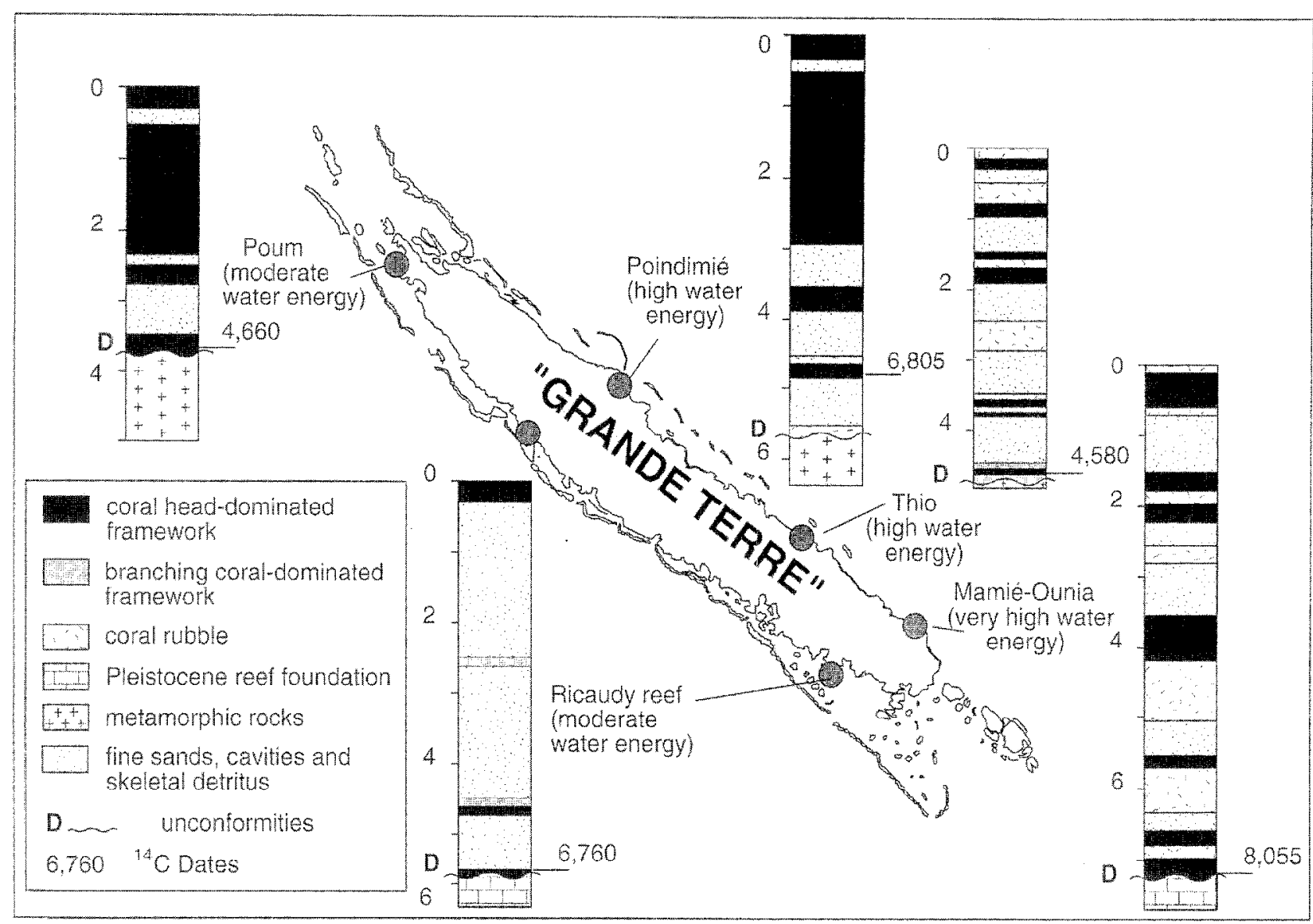

Figure 3. Core logs of some typical fringing reefs. ${ }^{14} \mathrm{C}$ dates are given in calendar years BP.

The ages of the earlier Holocene reef settlements in New Caledonia do not extend beyond $8.5 \mathrm{ka}$. The most likely explanation, supported by results from Australia [31,33] and Vanuatu $[2,3]$, is that sea surface temperatures (SST) around New Caledonia (19-23 $\mathrm{S}$ ) were too cold prior to $8.5 \mathrm{ka}$ to promote significant reef development. In addition, two categories of reefs can be distinguished according to their age of settlement. The earliest settled prior to $5 \mathrm{ka}$, preferentially in the south of the Grande Terre overtopping karstified substrates. A second phase of settlement occurred later than $4 \mathrm{ka}$, especially in the north of the Grande Terre, and generally over non-carbonate rocks (figure 3). This offset in fringing reef initiation seems to be linked to the nature of the substrate and also, to a lesser extent, to the local hydrodynamic regime. The roughness of karst surfaces may have facilitated recruitment and attachment of coral larvae and successfully catalyzed coral growth [8]. This assumption is in agreement with observations from the Australian Great Barrier Reef [16, 27].

\subsection{The 125-ka-old reef}

Underneath the fringing and barrier reefs, the 125-ka-old unit is generally capped by calcretes resulting from a relatively long period of emergence. Locally, it is affected by freshwater alteration and, in this situation, no suitable samples are available for dating. However, the barrier reef is frequently unaltered, and several alpha counting U/Th dates have been obtained: $125 \pm 20 \mathrm{ka}$ at Ténia [15], $135 \pm 12.8 \mathrm{~kat}$ at Ilot Vert [18] and 125 $\pm 1 \mathrm{ka}$ and $131 \pm 1 \mathrm{ka}$ at Ilot Amédée respectively in cores Amédée 1 and 2 [9]. Additional dates ranging from 115 to $144 \mathrm{ka}$ were also obtained by the TIMS method on corals from cores 4 and 5 at llot Amédée [42].

Underneath the fringing reefs, the $125 \mathrm{ka}$ unit is predominantly composed of biocalcarenites rich in articulated and branched coralline algae, Halimeda, molluscs, echinids and foraminiferids, associated with scattered encrusting algal and coral buildups. The 125-ka-old fringing reef 


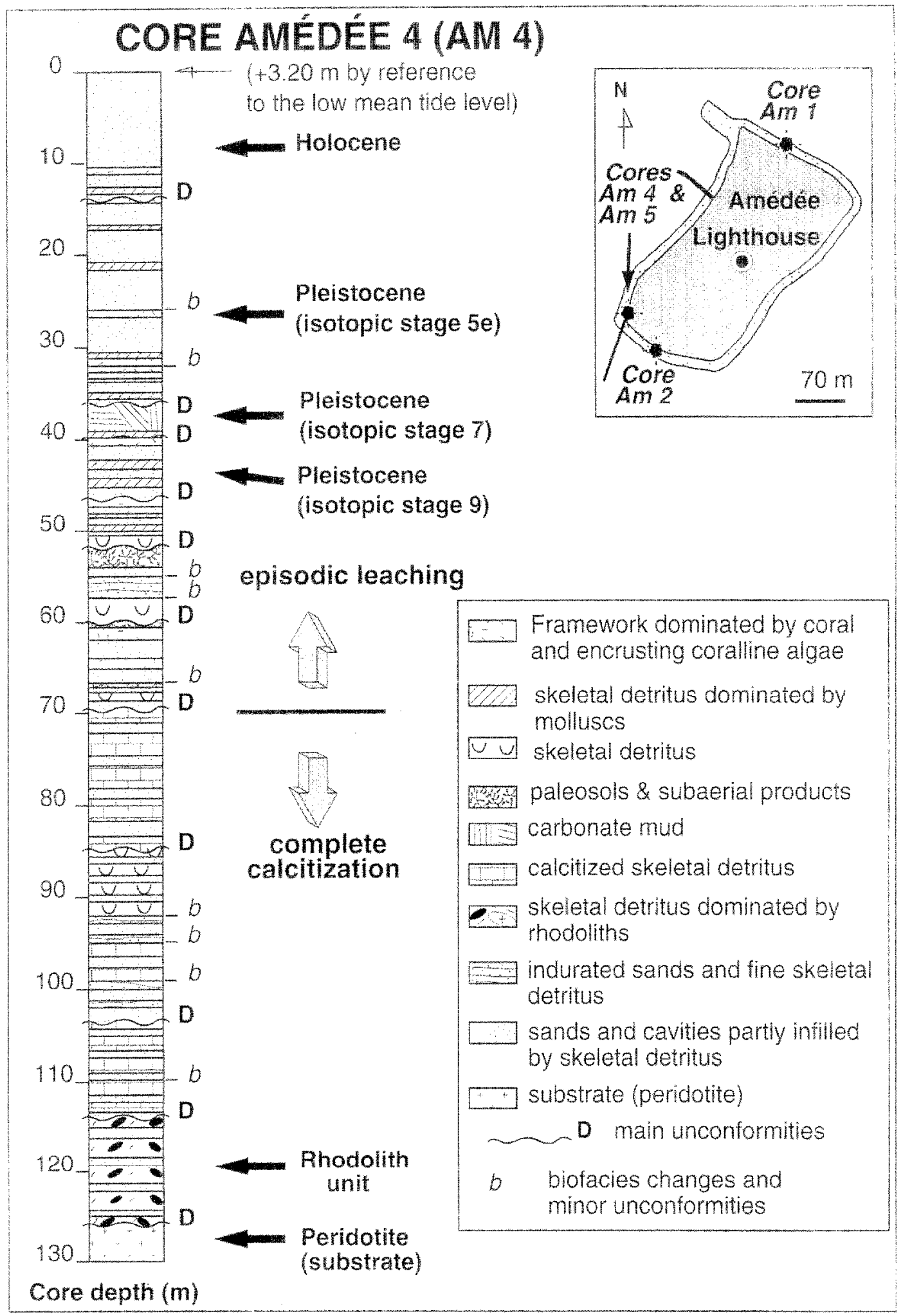

Figure 4. Schematic lithology of core Amédée 4. 

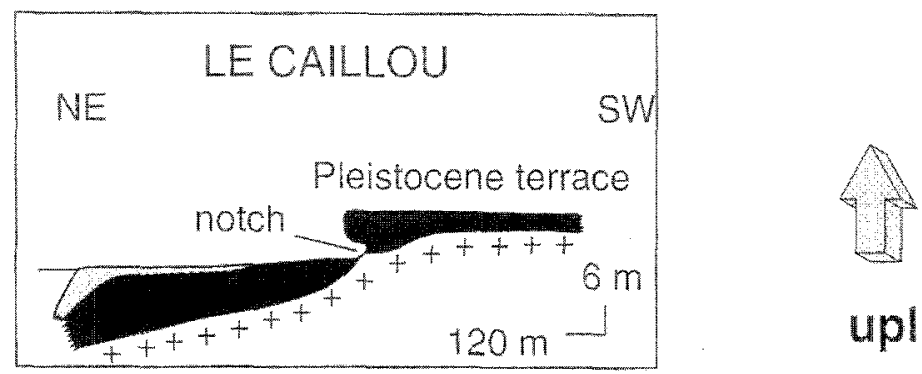

uplitt

A : Holocene reef downstepping the $125 \mathrm{ka}$-old reef terrace
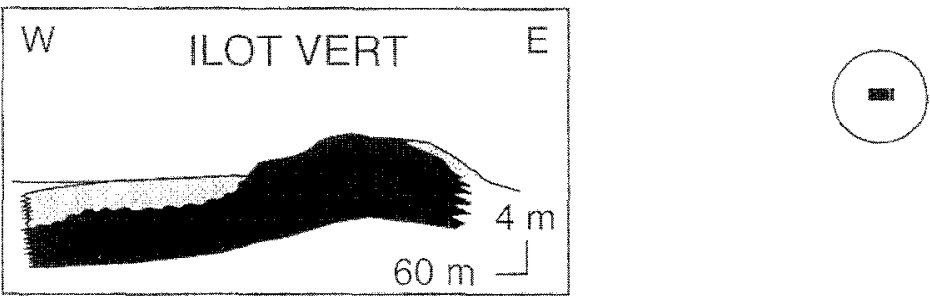

B: Holocene reef downstepping a relict of $125 \mathrm{ka}$-old reef

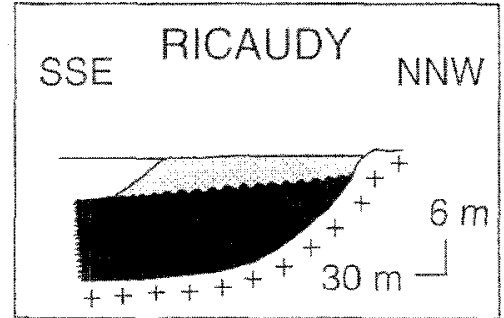

\section{subsidence}

C: Holocene reef overlying the 125 ka-old reef
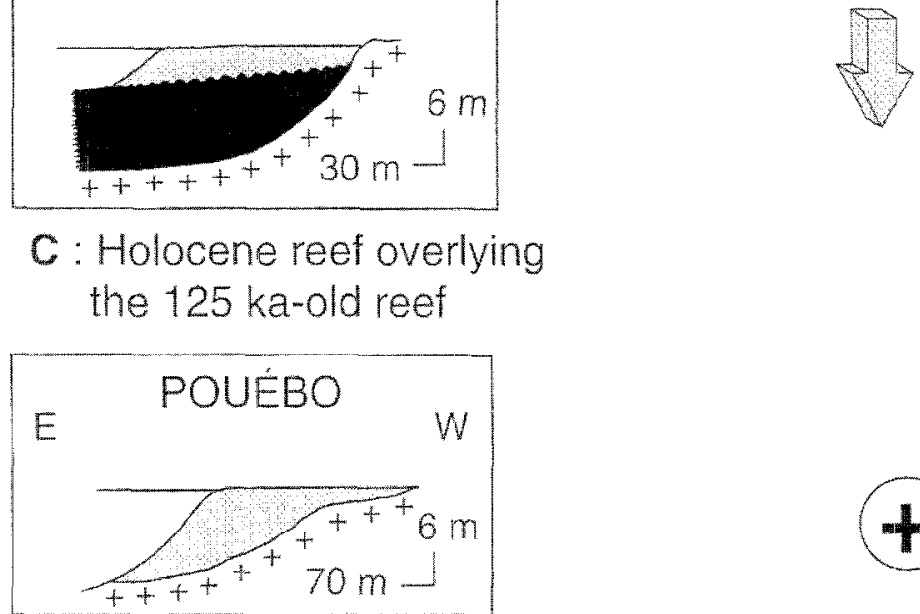

D: Holocene reef directly overlying the bedrock Holocene reef 


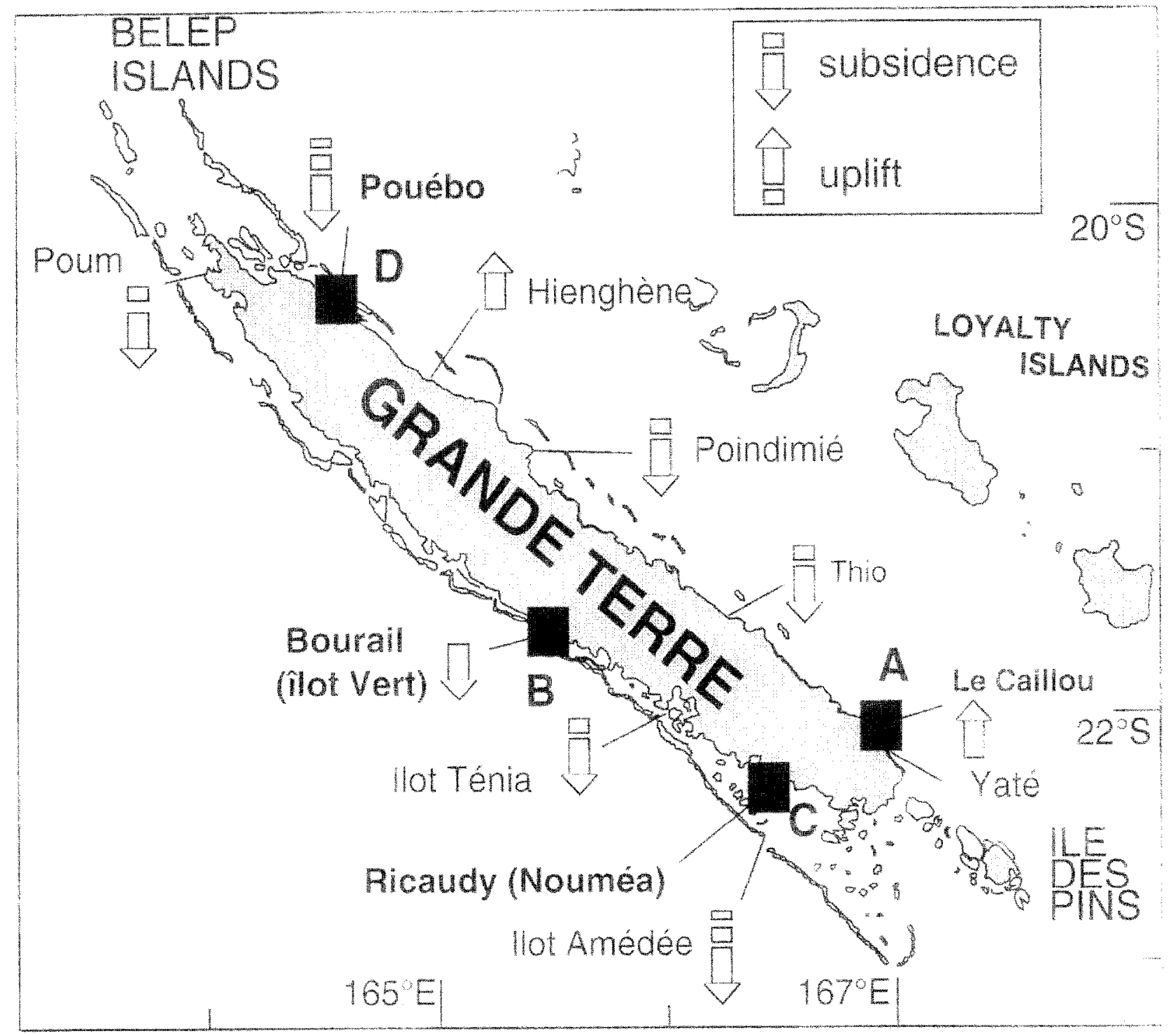

Figure 6. Neotectonic behaviour (uplift and subsidence motions) of the margins of the Grande Terre, New Caledonia.

is absent in cores from the eastern and northern coasts probably due to active subsidence. This contention is supported by the morphology of the reef system. However the 125 -ka-old reef was reached by drilling at d'Entrecasteaux reefs, offshore of the northern end of the Grande Terre [18]. Therefore, in the eastern and northern part of the Grande Terre, the 125-ka-old reefs are probably sub merged offshore [9].

Underneath the barrier reef, at Ilot Ténia, the 125-ka-old unit consists of a framework of corals, bryozoans and coralline algae trapped in bioclastic products rich in bryozoans, coralline algae, Halimeda, molluscs and echin- ids, typical of reef flat facies [15]. Similarly, at llot Amédée, the 125-ka-old reef consists of a framework of corals and coralline algae with a few bioclastic beds, typical of reef flat facies. At llot Vert, skeletal deposits (coralline algae, molluscs and foraminifera) and scarce coral forms are typical of back reef zones [7, 18].

The 125-ka-old reef units are markedly enriched in Halimeda beds. Such a richness was previously reported from the 125-ka-old reefs cored on the Australian Great Barrier Reef $[28,32]$. This abundance in Halimeda could be linked to a nutrient enrichment of the waters $[16,26]$. 


\subsection{The older Pleistocene units underneath the modern barrier reef system}

Older Pleistocene reef units were only encountered in the barrier reefs. This is consistent with what was previously reported from Ilot Ténia [15]. More recently, coring on Ilot Amédée brought evidence for successive reef stages of Pleistocene age, particularly well documented in core Amédée 4 (figure 4).

The substrate, composed of peridotite, was reached at $126.50 \mathrm{~m}$ depth at Amédée. Each overlying reef unit is capped by unconformities identifiable by calcareous crusts or paleosoils and dissolution features reflecting subaerial phases. The unconformity at $14 \mathrm{~m}$ core depth occurs in the form of fragments of a mm-thick calcareous crust induced by emergence. The Pleistocene 125-ka-old reef is found from 14 to $37 \mathrm{~m}$ depth. TIMS dates yield ages ranging from $144 \mathrm{ka}$ at the top to $116 \mathrm{ka}$ at the bottom of the unit. The apparent inversion of these ages, already recognized elsewhere [24], is linked to ${ }^{230} \mathrm{Th}$ and ${ }^{234} \mathrm{U}$ mobility, related to the occurrence of a microporous network reflecting slight freshwater dissolution of corals during emergence [42]. A unit composed of coralgal framework, mudstones and skeletal detritus mainly made of foraminiferids and algae, is found from $37 \mathrm{~m}$ to $47 \mathrm{~m}$ depth, and characterizes sub-reefal environments. This unit is dated by TIMS at about $260 \mathrm{ka}$. This unrealistic date probably results from the diagenetic mobility of $U$ and Th isotopes which in this case yield dates too old [42]. On the basis of stratigraphical succession, this unit probably corresponds to the isotopic stage $7(210 \mathrm{ka})$. At around $41 \mathrm{~m}$ core deep, an unconformity may indicate the transition to the isotopic stage 9 (330 ka); unfortunately this assumption cannot be supported by U/Th dates. At $47 \mathrm{~m}$ core deep, a sharp change occurs in the reef growth pattern. From 47 to $69.50 \mathrm{~m}$ depth, the reef sequence is punctuated by several minor discontinuities and displays an increase of diagenetic alteration downward. From 47 to $52 \mathrm{~m}$ core decp, coral assemblages are scarce; muddy beds dominate the facies, trapping molluscs, echinids, foraminifera, Halimeda, coralline algae and rare corals. At $52 \mathrm{~m}$ core deep, subaerial alteration expressed by moldic and solution features associated to terrigeneous material indicates the occurrence of another diagenetic unconformity. From 52 to $60 \mathrm{~m}$ core deep, the sedimentary unit is composed of muddy beds which include scarce molluscs and silt-grained detritus. An unconformity, similar in nature to the $52 \mathrm{~m}$ unconformity is recognized at $60 \mathrm{~m}$ core deep. From 60 to $69.50 \mathrm{~m}$ core deep, molluscs are abundant while coral elements are rare. At $69.50 \mathrm{~m}$, the reef material is severely calcitized. From 69.50 to $116 \mathrm{~m}$ depth, the sequence exhibits recrystallized corals, molluses and abundant micritic deposits. Dissolution and calcitization features indicate a long period of emergence. From 116 to $126.50 \mathrm{~m}$ depth, a clear change in deposition is observed, characterized by the abundance of rhodoliths and molluscs and a relative scarcity of corals.

The successive reef units recognized in core Amédée 4 developed during high sea-stands from the mid-Quaternary to the Holocene. In tropical areas, few data are available on the stratigraphy of barrier and atoll reefs. In Mururoa atoll (French Polynesia), several unconformities were recognized and partly identified $[6,23]$ : during the isotopic stage 7 ( $210 \mathrm{ka}$ ) the sea probably reached its present level, while during the isotopic stages 9 (330 ka) and $11(430 \mathrm{ka})$, the sea could have been at -25 to $-30 \mathrm{~m}$ lower than present. These results are at odds with those obtained from emerged reef terraces: on the reef terraces from Indonesia [38], it is assumed that during interglacial isotopic stages 5,9 and 11 , the sea reached its present level and that during isotopic stage 7 , the sea was $-12 \pm$ $12 \mathrm{~m}$ lower than present. These results are based on the assumption that the uplift rate has remained constant. However, it appears that such a rate could vary through time, as observed in Papua New Guinea [36] or in Vanuatu, [10]. Benthic foraminifera $\delta^{18} \mathrm{O}$ isotopic values indicate that during the last intcrglacial isotopic stages (from 5 to 11) the sea level was similar or maybe slightly higher than at present [1]. By comparison with these values, and considering the subsidence rate of $0.14 \mathrm{~mm} \mathrm{yr}^{-1}$, the location of the interglacial isotopic stages 7 and 9 in core Amédée 4 are in agreement with interglacial high stands at a level close to the present one.

The lack of suitable foundations for reef colonization (i.e. peridotite), presumably combined to a period unfavourable to reef development, may explain the paucity of corals in this carly 'recfal' community. Aftcr a period of emergence, the flooding of the newly formed carbonate surface (at $116 \mathrm{~m}$ depth in core Amédée 4), proved more suitable for the recruitment and attachment of coral larvae and stimulated coral reef growth. This interpretation still remains speculative and further work is needed to reach a definite conclusion. Examination of the succession of the biological assemblages gives additional information on development of the barrier reef. The basal unit from 116 to $126.50 \mathrm{~m}$ is rich in rhodoliths, often poorly preserved, which hampers identification at the specific 
level. At present, environments rich in rhodoliths can be observed at the rear of the modern barrier reef (C. Payri and M. Pichon, pers. comm.) in relatively quiet settings. In tropical areas, the rhodoliths are encountered at depths of 20 to $60 \mathrm{~m}$ on the fore-reef and back-reef slopes [4]. The occurrence of rhodoliths in the basal unit is characteristic of the pioneer stage of barrier reef development. Such an occurrence indicates that the barrier reef settled on a shallow carbonate platform. In Australia, a similar deposit of rhodoliths was recognized in the pioneer stages of the Great Barrier reef formation, upon at platform at depths ranging from 30 to $80 \mathrm{~m}$ [5]. In New Caledonia, the sedimentary units which immcdiately followed the rhodoliths are mainly composed of molluscs and algae accompanied by corals, indicating sub-reefal environments (e.g. core Ténia [15]). The corals and encrusting algae become abundant in the upper part of the reef sequence and characterize the most recent interglacial stages.

The nature of unconformities provides valuable information on climatic conditions during the period of exposure (figure 4). The 125-ka-old reef, topped by a thin calcareous crust on the western and southwestern coasts, reveals slight dissolution of carbonates and poorly developed cementations (low-magnesian calcite). Such an alteration reflects dry climatic conditions when the reef was exposed. This suggests that the top of the 125-ka-old reef unit approximately corresponds to the original reef flat; hence, it can be used as an accurate reference level. In contrast, in core Amédée 4, at 52 and $60 \mathrm{~m}$ depth, the unconformities which are underlined by paleosoils of several tens of centimeters in thickness, are representative of a wet climate (figure 4). The severely calcitized reef sequence from 69.50 to $126.50 \mathrm{~m}$ indicates a long period of emergence.

\section{TECTONIC MOVEMENTS REVEALED BY THE ANALYSIS OF REEF UNIT DISTRIBUTION}

The distribution of Holocene and 125-ka-old reefal units reflects the subsiding behaviour of the New Caledonian ridge margins (figure 5): the existence of submerged and superimposed reefs indicate relatively high subsidence rates $\left(>0.1 \mathrm{~mm} \mathrm{yr}^{-1}\right.$ ), whereas juxtaposed units (occasionally, forming step-like recf terraces) indicates low subsidence rates $\left(<0.05 \mathrm{~mm} \mathrm{yr}^{-1}\right)$ and sometimes even slow uplifts.

Relics of the 125-ka-old fringing reef are exposed in three main places: in the Tara/Yaté and Hicnghènc arcas (eastern coast) and in the Bourail region (western coast) (figure 2). In the Yate area, in the southeast of the island. the last interglacial reef is uplifted along some $30 \mathrm{~km}$ of coastline, reaching a maximum elevation of $10 \mathrm{~m}$. This is higher than is generally admitted (i.e. $+6 \mathrm{~m}$ ) for the sea level position at $125 \mathrm{ka}$. On the east coast, near Hiengène, the relics of the last interglacial reef are less extensive than in Yaté, but have been uplifted to $+13 \mathrm{~m}$ above sea level. Offshore of Hienghène and Yate, the barrier reef is submerged down to 15 to $20 \mathrm{~m}$ water-depth and is subdivided into two or three distinct reefs, due to tectonic collapse. This illustrates particularly well the effects of the fault-flexure system which controls the margins [22]. In Bourail on the western coast, the 125 -ka-old reef is lower than $+6 \mathrm{~m}$ and reflects a slight subsidence of the area $\left(0.03 \mathrm{~mm} \mathrm{yr}^{-1}\right)$. Elsewhere, the 125-ka-old fringing recf lies under the Holocene reef or is submerged offshore: in the southwest of the island, the Holocene-Pleistocene (125 ka) unconformity is at $-3 \mathrm{~m}[7,30]$. In areas of relatively high subsidence rates, such as in the northwest or northeast of the island, the 125-ka-old fringing reef has subsided so much that the Holocene reef rests directly on a metamorphic or old sedimentary substratum. Finally, within the barrier reef build-up, the 125-ka-old reef flat is overlain by a Holocene formation, the thickness of which depends on local subsidence.

The overall setting of the 125-ka-old reef around New Caledonia is the result of the irregular subsidence having affected the island northward and southwestward from a relatively stable central zone including the Bourail area to the west and Yaté/Tara and Hienghène areas to the east (figure 6). Subsidence rates markedly increase seaward as, for instance, in the Nouméa lagoon and the Yaté barrier reef. The New Caledonian ridge seems to have undergone a continuous double warping during the past $125 \mathrm{ka}$. This longitudinal and transversal warping is characteristic of the vertical tectonic behaviour of the ridge since Miocene times: the continuous subaerial erosion of the peridotitic sheet induced isostatic vertical readjustments of the Grande Terre, accompanied by filling of the two adjacent basins and collapse of the margins due to gravity.

\section{SUMMARY AND CONCLUSION}

In New Caledonia, the settlement of the Holocene reefs took place no more than $8.5 \mathrm{ka}$ ago, suggesting that prior to this time, SST were too cold for the establishment of reefs. The earliest stages of reef initiation seem to be linked to the availability of karstified limestone foundations, since the roughness of the substrate has facilitated 
recruitment and attachment of coral larvae. Generally, the biofacies of the fringing reefs are distributed within two units. A basal unit, typical of low to medium water energy conditions, and an upper unit of medium to high water energy conditions, reflecting a catch-up style of reef growth. Although internal structures within the barrier reef zone are poorly understood due to a lack of cores, a preliminary scheme can be presented. The Holocene reef units from Ténia and Amédée are composed respectively of bioclastic products typical of backreef deposits, and tramework characteristic of reef edges and upper reef slopes exposed to strong wave action. Below the fringing reefs, the Pleistocene material is only represented by the 125 -ka-old unit while within the barrier reef it is characterized by a succession of reef units separated by more or less conspicuous unconformities. Within the 128-m-long core Amédée 4, a series of Pleistocene units have been identified. U/Th dates obtained by TIMS indicate the occurrence of isotopic stage 5 (125 ka) and possibly of isotopic stages 7 (210 ka) and 9 (330 ka). Below, several reef units can be distinguished down to $126.5 \mathrm{~m}$ depth. All these units were probably built up during high sea-stands in the mid to Late Quaternary. Concerning the initiation of the barrier reefs, a similar scheme is observed in Australia and New Caledonia.
In both areas, a rhodolith unit constitutes the pioneer stage of development of the barrier reef.

Although the sedimentological and stratigraphical analyses of cores extracted from the fringing and barrier reefs yield valuable data on the mode of edification and on the vertical tectonic behaviour of the island, many problems are still unsolved, and this paper should be viewed as a preliminary study.

\section{Acknowledgments}

The authors thank Y. Join, J.L. Laurent, C. Ihilly and D. Utramadra (IRD) for their participation on the field work, the "Phares et Balises" Service, Lieutenant de Vaisseau Le Tessandier and Mâ̂tre Principal Philipot (Marine Nationale) for their assistance and Province Sud of Ncw Calcdonia for pcrmits to drill. Thanks to R. Notonier (Univ. Provence) and M. Gérard (IRD) for their assistance in SEM microscopy. The authors also thank L. Montaggioni and anonymous referees for constructive reviews. This work is supported jointly by IRD, LSCE and PNRCO (Programme National sur les Récifs COralliens).

\section{REFERENCES}

[1] Bard E., Jouannic C., Hamelin B., Pirazzoli P.A., Arnold M., Faure G., Sumosusastro P., Syaefudin, Pleistocene sea levels and tectonic uplift based on dating of corals from Sumba Island, Indonesia, Geoph. Res. Lett. 23 (1996) 1473-1476.

[2] Beck J.W., Edwards R.L., Ito E., Taylor F.W., Récy J., Rougerie F., Joannot P., Hénin C., Sea surface temperature from coral skeletal Strontium/Calcium ratios, Science 257 (1992) 644-647.

[3] Beck J.W., Récy J., Taylor F.W., Edwards R.L., Cabioch G., Abrupt changes in Early Holocene tropical sea surface temperature from coral Sr/Ca thermometry, Nature 385 (1997) 705707.

[4] Bosence D.W.J., The occurrence and ecology of recent rhodoliths, in: Peryt T.M. (Ed.), Coated Grains, Springer-Verlag, Berlin Heidelberg, 1983, pp. 225-242.

[5] Braga I.C., Agnirre T., The environmental significance of coralline red algae in Ribbon 5 drill hole (Great Barrier Reef, NE, Australia), The tenth Edgeworth David Symposium "Funafuti to Mururoa: a century of reflections on carbonate reservoirs", Sydney, 4-5 September 1997, abstract.

[6] Buigues D., Mururoa and Fangataufa: sea-level changes, karstification and the atoll morphology, Bull. Soc. Géol. France 169 (1996) 373-382.
[7] Cabioch G., Récifs frangeants de Nouvelle-Calédonie (Pacifique Sud-Onest). Structure interne et influences de l'eustatisme et de la néotectonique, thèse doct. univ. Aix-Marseille-I, 1988.

[8] Cabioch G., Montaggioni L.F., Faure G., Holocene initiation and development of New Caledonian fringing reefs, SW Pacific, Coral Reefs 14 (1995) 131-140.

[9] Cabioch G., Récy J., Jouannic C., Turpin L., Contrôle environnemental et néotectonique de l'édification récifale en Nouvelle-Calédonie au cours du Quaternaire terminal, Bull. Soc Géol. France 167 (1996) 729-742.

[10] Cabioch G., Taylor F.W., Récy J., Edwards R.L., Gray S.C., Faure G., Burr G., Corrège T. Environmental and tectonic influences on growth and internal structure of a fringing reef at Tasmaloum (SW Espiritu Santo, New Hebrides Island Arc, SW Pacific), in: Camoin G., Davies P.J. (Ed.), Reefs and carbonate platforms in the Pacific and Indian Oceans, IAS special publication 25 (1998) 261-277.

[11] Cabioch G., Montaggioni L.F., Faure G., Ribaud-Laurenti A., Reef coralgal assemblages as recorders of paleobathymetry and sea level changes in the Indo-Pacific province, Quater. Sci. Rev. (in press). 
[12] Chevalier J.-P., Coral reefs of New Caledonia, in: Jones O.A., Endean R. (Ed.), Biol. Geol. Coral Reefs 1, Acad. Press, New York, 1973, pp. 143-167.

[13] Collot J.Y., Missègue F., Malahoff A., Anomalies gravimétriques et structure de la croûte dans la région de la NouvelleCalédonie : enracinement des péridotites, Trav. Doc. Orstom 147 (1982) 549-564.

[14] Collot J.Y., Malahoff A., Récy J., Latham G., Missegue F., Overthrust emplacement of New Caledonia ophiolite: geophysical evidence, Tectonics 6 (1987) 215-232.

[15] Coudray 3., Recherches sur le Néogène et le Quaternaire marins de la Nouvelle-Calédonie. Contribution de l'étude sédimentologique à la connaissance de l'histoire géologique postéocène de la Nouvelle Calédonie. Expédition française sur les récifs coralliens de Nouvelle-Calédonie 8, Fondation SingerPolignac, Paris, 1976, 276 p.

[16] Davies P.J., Marshall J.F., Hopley D., Relationships between reef growth and sea level in the Great Barrier Reef, Proc. 5th Int. Coral Reef Congress 3, Tahiti (1985) 95-103.

[17] Davis W.M., Les côtes et les récifs coralliens de NouvelleCalédonie, Ann. Géogr. 34 (1925) 191 ; 244-269; 332-359; 423-441; 521-558.

[18] Degaugue-Michalski F.-M., Croissance et évolution d'édifices récifaux du Pacifique occidental (Nouvelle-Calédonie, Chesterfield) à l'Holocène et au Pléistocène, thèse doct. univ. AixMarseille-I, 1993.

[19] Done T.J., Patterns in the distribution of coral communities across the central Great Barrier reef, Coral Reefs 1 (1982) 95107.

[20] Dubois J., Launay J., Récy J., Les mouvements verticaux en Nouvelle-Calédonie et aux îles Loyauté et l'interprétation de certains d'entre eux dans l'optique de tectonique des plaques, Cah. Orstom, sér. Géol. 5 (1973) 3-24.

[21] Dubois J., Launay J., Récy J., Uplift movements in New Caledonia - Loyalty islands area and their plate tectonics interpretation, Tectonophysics 24 (1974) 133-150.

[22] Dugas F., Debenay J.P., Interférences des failles-flexures littorales et de l'érosion karstique sur les constructions coralliennes: le lagon de Nouvelle-Calédonie, C. R. Acad. Sci. Paris 287 (1978) 1091-1094

[23] Ebren Ph., Impact des variations rapides du niveau marin sur le développement des atolls au Quaternaire: Mururoa (Polynćsic françaisc), thèsc doct. univ. Aix-Marseille-I, 1996.

[24] Eisenhauer A., Zhu Z.R., Collins L.B., Wyrwoll K.H., Eichstätter R., The last interglacial sea level change: ncw cvidence from the Abrolhos islands, West Australia, Geol. Rundsch. 85 (1996) 606-614.

[25] Faure G., Recherche sur les peuplements des scléractiniaires des récifs coralliens de l'archipel des Mascareignes (océan Indien occidental), thèse doct. sci. univ. Aix-Marseille-II, 1982.

[26] Hallock P., Schlager W., Nutrient excess and the demise of coral reefs and carbonate platforms, Palaios I (1986) 389-398.
[27] Hopley D., Slocombe A.M., Muir F., Grant C., Nearshore iringing reefs in north Queensland, Coral Reefs 1 (1983) 151160.

[28] Johnson D.P., Cuff C., Rhodes E., Holocene reef sequences and geochemistry, Britomart Reef, Central Greal Barrier Reef, Australia, Sedimentology 31 (1984) 515-529.

[29] Krocnke L.W., Cenozoic tectonic development of the Southwest Pacific, UN/ESCAP CCOP/SOPAC Techn. Bull. 6 (1984) 1-122.

[30] Lecolle J.F., Cabioch G., La limite holocène-pléistocène dảns le récif frangeant Ricaudy (Nelle-Caléd.). Géochronologie, faciès et diagénèse, Implications eustatiques et néotectoniques, Mar. Geol. 81 (1988) 241-260.

[31] Lund M., Davies P.J., Shelf edge algal dominated deep water buildups in the Capricorns, Southern Great Barrier Reef, International Workshop "Reefs and carbonate platforms in the Pacific and Indian oceans", Sydney, 1995, abstract.

[32] Marshall J.F, I.ithology and diagenesis of the carbonate foundations of modern reefs in the Southern Great Barrier Reef, BMR J. Aust. Geol. Geophys. 8 (1983) 253-265.

[33] Marshall J.F., Potential effects of oceanic deep waters on the initiation and demise of coral reefs, Proc. 6th Int. Coral Reef Symp. 3, Townsville (1988) 509-512.

[34] Montaggioni L.F., Cabioch G., Camoin G.F., Bard E., RibaudLaurenti A., Faure G., Déjardin P., Récy J., A 14,000 years continuous record of reef growth in a mid-Pacific island, Geology 25 (1997) 555-558.

[35] Neumann A.C., Macintyre I., Reef response to sea level rise: keep-up, catch-up or give-up, Proc, 5th Int. Coral Reef Congress 3, Tahiti (1985) 105-110

[36] Ota Y., Chappell J., Kelley R., Yonekura N., Matsumoto E., Nishimura T., Head J., Holocene coral reef terraces and coseismic uplift of Huon Peninsula, Papua New Guinea, Quater. Res. 40 (1993) 177-188.

[37] Paris J.P., Géologie de la Nouvelle-Calédonie, Mém. Bur. Rech. Géol. Min. 113 (1981) 1-278.

[38] Pirazzoli P.A., Radtke U., Hantoro W.S., Jouannic C., Hoang C.T., Causse C., Rorel-Best M., Quaternary raised coral reef terraces on Sumba island, Indonesia, Science (1991) 1834 1836.

[39] Routhier P., Étude géologique du versant occidental de la Nouvelle-Calédonie entre le col de Boghen et la pointe d'Arama, Mém. Soc. Géol. Fr. 32 (1953) 1-271.

[40] Stuiver M., Reimer P.J., Extended ${ }^{14} \mathrm{C}$ data base and revised calib $3.0{ }^{14} \mathrm{C}$ age calibration program, Radiocarbon 35 (1993) $215-230$

[41] Thomassin B.A., Vasscur P., The coral reef complexes of the S.W. coast of New Caledonia: building and geomorphology, Proc. 4th Int. Coral Reef Symp. 3, Manilla, 1981, 66 p.

[42] Turpin L., Cabioch G., Jean-Baptiste P., Bonhomme P., Recy J., Evidence for diagenetic redistribution of U-series elements in a coral reef, New Caledonia, Earth Plan. Sci. Lett. (submitted). 